\title{
Analysis on the Financing Risk of International Trade \\ Liyuan $\mathrm{Li}^{1, \mathrm{a}}$ \\ ${ }^{1}$ Nanyang Institute of Technology, Nanyang, Henan, 473004 \\ ${ }^{\mathrm{a}}$ email
}

Keywords: International Risk, Financial Management, Analysis Theory

\begin{abstract}
With the development of China's foreign trade and the intensification of banking competition, international trade finance has become a financial business of commercial banks. The business not only for the import and export enterprises to provide financing facilities, but also to expand the banking business in the wave of economic globalization, trade finance has been widely cultivated as an international commercial banks, the effectiveness of new points. However, in the practice of trade finance is also lurking all kinds of risks, if not properly grasp, import and export business risk will be directly passed on to the bank. How to prevent and control the risk of trade financing business has become a bank to expand business needs to be resolved. Especially in the continuous development of trade finance innovation business today, this issue is particularly important. This paper focuses on the analysis of the risks encountered by banks in the process of international trade financing and explores the countermeasures to effectively control and prevent the potential risks of trade finance to promote the development and innovation of trade finance business.
\end{abstract}

\section{Introduction}

Import and export trade from negotiation, signing to compliance is a commercial credit, therefore, the import and export enterprises on both sides of the business capacity, import and export goods quality, price, delivery time, market conditions and exchange rate changes and the manufacturer's production capacity And many other factors will affect the smooth completion of the trade. During this period, the emergence of any unfavorable factors, are likely to lead to business failure, resulting in trade disputes, the emergence of trade risks, leading to risk loans. The settlement of letters of credit is one of the most common forms of settlement in international trade. Therefore, trade in credit is becoming more and more widely used as a means for various commercial banks to expand international settlement business, strengthen their competitiveness and improve their operating efficiency. However, due to the development of the business in the early stages of the bank, did not implement its strict management of the operation, to take effective preventive measures, resulting in a lot of system lax, poor supervision, management disorders and other operational losses caused by the risk of loss of funds. The transactions between the two parties are commercial credit, and the banks of both sides of import and export play a key role in promoting the smooth conduct of both parties' transactions. Only to choose a good credit with the agent line in order to make trade from commercial credit into bank credit, but in practice often encounter each other bank credit is not good, unreasonable protest and the bank itself bankruptcy, bankruptcy, etc. For bad debts, the bank suffered losses. The banks of both sides of import and export play a key role in promoting the completion of trade. Foreign banks are not common to banks in China. Banks are operated according to the principle of commercial operation, such as poor management and may be closed at any time. In addition, some developing countries do not know enough about trade and financial practices or do not follow the usual practice. Some issuing firms often require importers to demand unreasonable claims against credit. Some defenders have ignored international practice to shirk their first the payer should bear the responsibility. This kind of bank credit poor situation, will also cause risk loans. Therefore, it is important to choose a good proxy line. 


\section{International Trade Financing Business Application Advantages}

Trade finance as a means of promoting financial import and export trade, both for banks or enterprises are of great value, with a wide range of business development space. First of all, the banks in terms of trade finance and other business compared to a less risky, relatively safe credit behavior. Banks to provide trade financing to enterprises in terms of risk, repayment sources, guarantee methods, effective supervision and so on are better than the general loan, the bank is an effective way to effectively use the funds; trade financing is also a high profit, Business. In addition to the deposit and loan spreads, the trade finance business can bring a variety of benefits: the bank can earn various fees by providing credit facilities to the enterprises and handling the documents in the settlement. Trade financing, the bill also has the right to recourse, the bank has the right to recourse to the beneficiary has been paid and delayed payment of interest; bank to the exchange of money, Trade finance as a link, but also to further close the relationship with the enterprise, so that the bank in the full range of services to win more business. Therefore, in modern business practice, banks have provided trade finance as an important means to compete for customers and business, and enhance the competitiveness of banks. Trade finance is actually a loan under settlement, which is directly linked to a particular sales activity. Once the sale is realized, the bank providing the loan can deduct the principal and interest from the funds recovered from the settlement, and the loan and recovery time is usually not more than three months. The cycle is very short and the cash flow rate is faster.

From the enterprise point of view, the use of trade finance is a foreign trade enterprises to raise funds, enhance competitiveness, expand the international market, an effective way to expand exports. Capital is the blood of enterprises, business activities is the first driving force and sustained driving force. If the shortage of funds, it can not expand the reproduction, improve technology, more inability to develop new products and enhance competitiveness. Especially in developing countries, foreign trade enterprises in the face of intense competition in the international market pressure, but also had to consider to provide diversified payment to the concessions, but in the payment of the concessions and flexibility means that foreign trade enterprises to Facing greater risk, but also account for capital. In this case of dilemma, foreign trade enterprises tend to fear or unable to take risks out of competition, thus losing the market. Importers are often due to lack of funds and operational difficulties. International trade finance is a kind of financial support means which can meet the needs of both importers and exporters. It can eliminate the worries of importers and exporters by providing financial services such as financing, insurance and guarantee to importers and exporters to help enterprises enter the international Market development business, improve competitiveness, promote international trade development. In short, the international trade financing has the advantages of small risk, high profitability, strong liquidity, can bear the risk of transfer or defuse the risk of the buyers and sellers, provide financing and financial services, and has been widely cultivated as an international business in the tide of economic globalization Bank of the benefits of new points.

\section{Major Risks of International Trade Financing}

International trade financing is based on international trade, it not only involves domestic and foreign trade markets, involving different legal rules and many aspects of complex links, and integration of imports and exports are closely linked to the bank and commercial dual credit , So there are a lot of potential risks to each bank's trade finance business.

International import and export trade from negotiation, signing to compliance is a commercial credit, for which the import and export enterprises on both sides of the credit status, operational capacity, import and export goods prices, quality, delivery time, market conditions and exchange rate changes Situation and enterprise production capacity and many other factors will affect the smooth completion of the trade. During this period, any part of the problem, are likely to lead to business failures, resulting in trade disputes and claims, there are trade risks, leading to risk loans. 
China's import and export enterprises in general poor efficiency, some loss of business management confusion, poor credit, often due to shortage of funds and the use of bills, loans and other letters of credit financing means to take bank funds. Short-term financing of banks is often occupied by long-term, seriously affecting the liquidity and security of bank operating assets. The banks of both sides of import and export play a key role in promoting the completion of trade. Foreign banks are not common to banks in China. Banks are operated according to the principle of commercial operation, such as poor management and may be closed at any time. In addition, some developing countries do not know enough about the trade and financial practices or do not practice at all. Some issuing firms often require importers to demand unreasonable claims against credit. Some defenders have ignored international practice to shirk their first the payer should bear the responsibility. This kind of bank credit poor situation will also cause risk loans. Therefore, it is important to choose a good proxy line. Whether the economy of the importers and exporters in the country is stable, whether the law is sound, whether the trade and foreign exchange control are strict and so on are essential to the smooth conduct of trade. Because trade finance involves the settlement and payment of creditor's rights and debts between different countries, when the host country is unstable, foreign exchange control, sanctions and other factors, may make the trade contract difficult to fulfill, so that the bank's trade financing risk. Therefore, ignoring the national risk, there may still be a risk loan.

\section{Measures to Prevent the Risk of International Trade Financing}

The rational establishment and division of labor within the bank organization is an important measure to ensure the smooth progress of trade finance business and to resist various risks. Therefore, in order to meet the needs of business development, banks should redesign the establishment of the organization, the business operation mode to do the appropriate adjustment and reform, to achieve both effective risk control and active customer service purposes. First, trade finance is a credit business and must be included in the Bank's credit management. The credit department of the trade finance customers to credit assessment, according to the credit line management regulations to determine the amount of trade financing granted to customers, focusing on reviewing the customer's credit level, the previous trade financing business records, credit status, financial status, management level and development Foreground, and thus to initially establish the amount of credit to customers. Second, set up a loan approval committee within the bank. The loan approval committee shall be composed of the credit department, the finance department, the planning department, the supervision department, the manager of the international business department and the president and the president. Should be based on the credit department of the initial review of the views of the credit department for each customer credit and financial status of the assessment and assessment, the total amount of credit approved by the customer and the amount of trade financing, including the establishment of issuing credit, import bill and export The amount of the amount of money, the amount of lump sum and other specific amount. Credit Department in accordance with the examination meeting of the credit standards, opinions and customers signed a credit agreement, requiring customers to apply for a timeliness of the security and mortgage procedures. The international business department and other business organizations can handle the relevant trade financing business according to the credit line drawn by the credit department. The credit risk of the actual trade finance is controlled by the credit department and the credit administration. The risk of international settlement is controlled by the international business department. In the unified credit management system, it is under the separation of credit, the risk of special control.

Banks should make full use of the report to grasp the ability to pay the business and whether there is sufficient material guarantee, because the import and export enterprises have large borrowing, large accounts receivable, large inventory, large cost, long-term investment, large exchange rate and small assets, Small investment efficiency, small solvency and other characteristics, determines the foreign trade enterprises scalability, the potential risk. So the analysis of the financial situation is essential. The bank's assessment of the financial situation of the firm must be based on the authenticity of the report and otherwise the risk to the bank is immeasurable. 
In addition, the quality of enterprise management, management efficiency and business capacity assessment is also an indispensable content of trade finance credit assessment work.

\section{Conclusion}

With the rapid development of trade and the intensification of banking competition, the demand for trade finance is more urgent. However, the real trade financing can not meet the needs of international trade both in terms of mode, business quantity and legal perfection. The reality forces us to face and face the risks, and we must vigorously develop the trade finance business under the premise of effectively avoiding and controlling the risk of trade finance. It should be pointed out that trade needs financing, financing risk, but as long as the establishment of a complete set of trade finance risk prevention system and operational mechanisms to regulate the business operations, trade risk can be managed to a minimum level, so as to promote trade financing business Rapid development.

\section{References}

[1] Jiang Quan, Ding Xiuying. Risk and Prevention of commercial banks in the financing of international trade [J]. Qinghai Finance, 2006 (12)

[2] Huang Haining. International trade financing business innovation trend [J]. New Finance, 2006 (11)

[3] Zhou Hui letters of credit and international trade finance - Analysis and Prospect [J]. Economic Issues, 2005 (08)

[4] Liu Jinghua. The international trade financing business thinking [J]. Gansu Finance, 2005 (01)

[5] Huixiao Feng, Sun Jiapeng. Commercial Bank Credit Risk Identification: Empirical Study of Credit Matrix [J]. International Finance Research, 2004 (03)

[6] Chen Yi. Chinese banking reform has been the bow winding [J]. International Finance, 2004 (03) 